Pathophysiology

of Haemostasis and Thrombosis
Pathophysiol Haemost Thromb 2005;34:23-28

DOI: $10.1159 / 000088544$
Received: November 2,2004

Accepted after revision: February 16, 2005

\title{
Evaluation of Urokinase-Type Plasminogen Activator and Its Receptor in Neointima of Polyester Vascular Grafts
}

\author{
Radoslaw Kowalewski ${ }^{\mathrm{a}}$ Lech Zimnoch $^{\mathrm{b}}$ Marek Z. Wojtukiewicz ${ }^{\mathrm{c}}$ \\ Jerzy Glowinski ${ }^{a}$ Stanislaw Glowinski ${ }^{\mathrm{a}}$ \\ Departments of ${ }^{\mathrm{a}}$ Vascular Surgery and Transplantology, ${ }^{\mathrm{b}}$ Medical Pathomorphology, and \\ ${ }^{\mathrm{c}}$ Oncology, Medical University of Bialystok, Bialystok, Poland
}

\section{Key Words}

Immunohistochemistry · Neointima • Polyester vascular graft - Urokinase-type plasminogen activator • Urokinase-type plasminogen activator receptor

\begin{abstract}
The aim of the study was to assess the expression of urokinase-type plasminogen activator (UPA) and its receptor (UPAR) in neointima of polyester vascular grafts. Anastomotic areas were examined at 1, 4 and 12 months after prosthesis implantation in dogs, as well as in human vascular grafts. Immunohistochemistry was performed for UPA and UPAR. Graft neointima in dogs was positively stained for UPA with increased intensity at 4 and 12 months, whereas uPAR expression appeared at 4 and its intensity was increased at 12 months. Intensive UPA and positive UPAR labeling was shown in human grafts. The results demonstrated that in the early period of the healing process of polyester vascular grafts only uPA is present in the neointima in the region of the graft to adjacent artery anastomosis, whereas in healed grafts in dogs and humans UPAR is found as well.
\end{abstract}

Copyright @ 2005 S. Karger AG, Basel

\section{Introduction}

The healing process of a polyester vascular prosthesis results in the formation of a graft wall that is composed of three layers. However, graft patency mainly depends on structural changes of the neointima [1-4]. Its luminal surface has fibrinolytic activity, and its impairment is assumed to be one of the factors predisposing to graft thrombosis [1, 5-7]. Furthermore, migration and proliferation of smooth muscle cells into the neointima initiates the development of intimal hyperplasia $[3,8]$. Both processes limit the success of prosthesis application in vascular surgery $[3,9]$.

The urokinase plasminogen activator (uPA) system is one of the factors involved in the regulation of fibrinolysis activation, as well as cell proliferation and migration. uPA expression was demonstrated in endothelial, smooth muscle cells and macrophages [10-12]. In spite of the commonly accepted involvement of uPA in cell proliferation and migration [13], its important role in fibrinolysis activation was also proved [10, 14]. The functions of uPA rely on binding to its receptor (uPAR), which protects uPA from inactivation and focuses its activity on the cell surface $[11,15]$. The receptor is present on macrophages and on endothelial and smooth muscle cells

\begin{tabular}{ll}
\hline KARGER & ( ) 2005 S. Karger AG, Basel \\
1424-8832/05/0341-0023\$22.00/0 \\
$\begin{array}{l}\text { Fax +41 61306 } 1234 \\
\begin{array}{l}\text { E-Mail karger@karger.ch } \\
\text { www.karger.com }\end{array}\end{array}$ & $\begin{array}{l}\text { Accessible online at: } \\
\text { www.karger.com/pht }\end{array}$
\end{tabular}

Radoslaw Kowalewski, MD

Department of Vascular Surgery and Transplantology

M.C. Sklodowskiej 24A st.

15-276 Bialystok (Poland)

Tel. +48 85 7468276, Fax +48 85 7468896, E-Mail korado@2com.pl 
[11]. It is involved in extracellular matrix remodeling and accelerates intimal growth by stimulating smooth muscle cell proliferation and migration $[12,16]$. Urokinase and its receptor were demonstrated in the neointima of stenosed or occluded vascular grafts [7, 8, 17]. However, the components of the uPA system in the neointima of patent prosthetic vascular grafts during the healing process are not recognized well enough.

The aim of the present study was to assess the expression of urokinase and its receptor in the neointima of patent polyester vascular grafts and to evaluate its changes in the process of graft healing.

\section{Methods}

The study protocol was accepted by the Committee for Ethics and Supervision on Human and Animal Research of the Medical University of Bialystok, Poland.

\section{Animal Graft Specimens}

Studies were carried out on 18 adult male and female mongrel dogs (weight range from 18 to $26 \mathrm{~kg}$ ). The animals were cared for in compliance with the 'Principles of Laboratory Animal Care'.

An infrarenal abdominal aorta was mobilized and a 6-cm-long segment was excised. A polyester double velour prosthesis - length $8.0 \mathrm{~cm}$; diameter $8.0 \mathrm{~mm}$ (Dallon; Tricomed SA, Lodz, Poland) was implanted with proximal and distal end-to-end anastomoses. Before implantation, prostheses were preclotted with autogenous blood [18]. Dogs were divided into three groups, 6 animals in each one. Grafts with a segment of normal aorta were harvested at 1, 4 and 12 months. For histological evaluation, tissue blocs with the distal anastomotic region of every graft were taken, washed with $0.9 \% \mathrm{NaCl}$ solution and incubated in acetone at $-18^{\circ} \mathrm{C}$. Samples of normal aorta were included as control material.

\section{Human Graft Specimens}

The studied material consisted of 4- to 5-cm-long distal fragments of aorto-femoral polyester vascular grafts obtained at revision surgery due to a false aneurysm of a distal anastomosis. The reconstruction was performed in 8 men age 58-74 years (63 years on average) with advanced atherosclerotic processes. Prosthetic bypasses from the prosthesis to the common femoral artery were performed in all cases at 36-60 months (40 months on average) after implantation of a polyester double velour prosthesis (Dallon). All subjects enrolled in the research signed an informed consent and found the protocol acceptable. Obtained graft segments were washed with $0.9 \% \mathrm{NaCl}$ solution and incubated in acetone at $-18^{\circ} \mathrm{C}$ directly after harvesting. Samples of normal aorta from 8 organ donors were included as control material.

\section{Immunohistochemistry}

All grafts and samples of normal aorta were fixed according to the AMeX method and embedded in paraffin [19]. For histological evaluation, 4- $\mu \mathrm{m}$ sections were cut transversely to the graft long axis, deparaffinized, rehydrated and stained for UPA and UPAR according to the avidin-biotin-peroxidase (ABC) method [20].
After blocking endogenous peroxidase activity with $3 \% \mathrm{H}_{2} \mathrm{O}_{2}$, the primary antibody was applied for $30 \mathrm{~min}$ at $37^{\circ} \mathrm{C}$. The following primary antibodies were used: rabbit polyclonal antibodies against uPA at a 1:50 dilution (code number 389; American Diagnostica, Greenwich, Conn., USA) and murine monoclonal antibodies against UPAR at a 1:100 dilution (code number 3963; American Diagnostica). A biotinylated secondary antibody was then applied for $30 \mathrm{~min}$, followed by an avidin-peroxidase conjugate for $45 \mathrm{~min}$ at $37^{\circ} \mathrm{C}$ (Vectastain Kits; Vector Laboratories, Burlingame, Calif., USA). To obtain a brown reaction product, slides were exposed to 3,3'-diaminobenzidine (DAB) and counterstained with hematoxylin.

The same antibodies were used for labeling of human and animal tissues. To confirm the specificity of immunological reactions, a control staining was performed for each group of examined tissue samples. In controls, the primary antibody was replaced with the same volume of $0.9 \% \mathrm{NaCl}$. The stains were compared and differences in positively stained areas were accepted as a marker of specific uPA and uPAR labeling.

Samples were assessed blindly by an experienced pathologist under light microscopy at $250 \times$ magnification and photographed. Results were scored from negative staining (-) to the extent of positively stained area: mildly positive, less than $25 \%$ positive cells per section $(+)$; moderately positive, $25-50 \%$ positive cells per section $(++)$ and strongly positive, more than $50 \%$ positive cells per section $(+++)$.

\section{Statistical Analysis}

Statistical analysis of differences of sample values between groups of animals was performed with the non-parametric KruskalWallis ANOVA test, accepting $\mathrm{p}<0.05$ as significant. Statistical differences of sample values between normal aorta and polyester vascular grafts in humans were assessed with the median test, accepting $\mathrm{p}<0.05$ as significant.

\section{Results}

\section{Animal Grafts}

All grafts were patent at the time of harvesting and their anastomotic areas were free from thrombosis and intimal hyperplasia. The average neointima thickness at the graft to artery anastomosis was approximately $180 \mu \mathrm{m}$ at 1 month, $540 \mu \mathrm{m}$ at 4 months and $550 \mu \mathrm{m}$ at 12 months. Expression of UPA and UPAR in normal aorta and neointima of polyester vascular grafts in dogs is shown in table 1.

Expression of UPA and UPAR was negative in normal dog aorta. In the neointima of polyester vascular grafts at 1 month after prosthesis implantation mildly positive $(+)$ staining for uPA was present only in single cells on the graft luminal surface in the anastomotic region (fig. 1). Labeling for uPAR was negative at that period of graft healing. At 4 months, strong (+++) expression of uPA was shown in cells covering the graft to adjacent artery anas- 
Table 1. Expression of urokinase and its receptor in normal aorta and neointima of polyester vascular grafts in dogs

\begin{tabular}{|c|c|c|c|c|}
\hline & \multirow{2}{*}{$\begin{array}{l}\text { Normal } \\
\text { aorta } \\
(\mathrm{n}=6)\end{array}$} & \multicolumn{3}{|c|}{ Graft neointima } \\
\hline & & $\begin{array}{l}1 \text { month } \\
(\mathrm{n}=6)\end{array}$ & $\begin{array}{l}4 \text { months } \\
(\mathrm{n}=6)\end{array}$ & $\begin{array}{l}12 \text { months } \\
(\mathrm{n}=6)\end{array}$ \\
\hline \multicolumn{5}{|c|}{ uPA expression } \\
\hline- & 6 & - & - & - \\
\hline+ & - & 4 & - & - \\
\hline++ & - & 2 & 1 & - \\
\hline+++ & - & - & 5 & 6 \\
\hline \multicolumn{5}{|c|}{ uPAR expression } \\
\hline- & 6 & 6 & - & - \\
\hline+ & - & - & 5 & 2 \\
\hline++ & - & - & 1 & 4 \\
\hline+++ & - & - & - & - \\
\hline
\end{tabular}

tomosis, as well as in cells of graft neointima (fig. 2). Mildly positive $(+)$ expression of UPAR was demonstrated at that period of graft healing in cells on the graft luminal surface and in graft neointima (fig. 3). At 12 months, expression of UPA in the neointima of polyester vascular grafts was very similar to that found at 4 months. Expression of UPAR had the same localization as in the previous period of the study, but its intensity was increased to moderate $(++)$. Differences in antigen expression among the studied groups of animals were statistically highly significant for uPA $(\mathrm{p}<0.0001)$, as well for uPAR ( $<<$ 0.0001).

\section{Human Grafts}

The luminal surface of all investigated grafts was covered by pannus ingrowth. Its average thickness ranged from 300 to $480 \mu \mathrm{m}$ ( $405 \mu \mathrm{m}$ on average). Expression of UPA and UPAR in normal aorta and the neointima of polyester vascular grafts in humans is shown in table 2 .

In normal aorta, moderately positive $(++)$ expression of uPA was demonstrated only in endothelial cells, whereas staining for UPAR was negative. In the neointima of polyester vascular grafts, strongly positive $(+++)$ expression of UPA was shown on its luminal surface, whereas cells of the graft neointima were stained with moderate $(++)$ intensity (fig. 4). Moderately positive $(++)$ expression of UPAR was present on the graft luminal surface, as well as in cells of the graft neointima (fig. 5). Differences in antigen expression between the neointima of polyester
Table 2. Expression of urokinase and its receptor in normal aorta and neointima of polyester vascular grafts in humans

\begin{tabular}{|c|c|c|c|c|}
\hline & \multicolumn{2}{|c|}{$\begin{array}{l}\text { Normal aorta } \\
(\mathrm{n}=8)\end{array}$} & \multicolumn{2}{|c|}{$\begin{array}{l}\text { Polyester graft } \\
(\mathrm{n}=8)\end{array}$} \\
\hline & $\begin{array}{l}\text { endothelial } \\
\text { layer }\end{array}$ & $\begin{array}{l}\text { subendo- } \\
\text { thelial layer }\end{array}$ & $\begin{array}{l}\text { graft } \\
\text { surface }\end{array}$ & $\begin{array}{l}\text { graft } \\
\text { neointima }\end{array}$ \\
\hline \multicolumn{5}{|c|}{ uPA expression } \\
\hline- & - & 8 & - & - \\
\hline+ & 2 & - & - & 1 \\
\hline++ & 6 & - & 1 & 6 \\
\hline+++ & - & - & 7 & 1 \\
\hline \multicolumn{5}{|c|}{ uPAR expression } \\
\hline- & 8 & 8 & - & - \\
\hline+ & - & - & 1 & 1 \\
\hline++ & - & - & 6 & 7 \\
\hline+++ & - & - & 1 & - \\
\hline
\end{tabular}

vascular grafts and the intima of normal aorta were statistically significant for uPA $(\mathrm{p}<0.01)$, as well as for uPAR $(\mathrm{p}<0.0001)$.

\section{Discussion}

Thrombosis and intimal hyperplasia belong to the most common complications in vascular surgery; they lead to graft occlusion $[3,4,9]$. The important role of the uPA system in both pathological processes is established $[7,8,12]$.

According to our results, species differences in uPA expression are present in normal aorta. Labeling for uPA was absent in dogs, whereas mildly positive staining was found in humans. The latter finding confirms the results of previously performed studies, which demonstrated the presence of UPA in normal human arteries and its enhanced expression in atherosclerotic lesions [12, 17]. It can be hypothesized that negative uPA staining in dog aorta may result from the destruction of epitopes recognized by the antibodies used, which took place during the fixation process [21]. However, this is a rather unlikely explanation, because uPA expression was negative only in dog aorta, whereas it was present in the neointima of vascular grafts in dogs that were fixed according to the same method. It seems that a more probable reason for this difference could be the absence of uPA in dog aorta or its presence at a low level below the detection limit. 

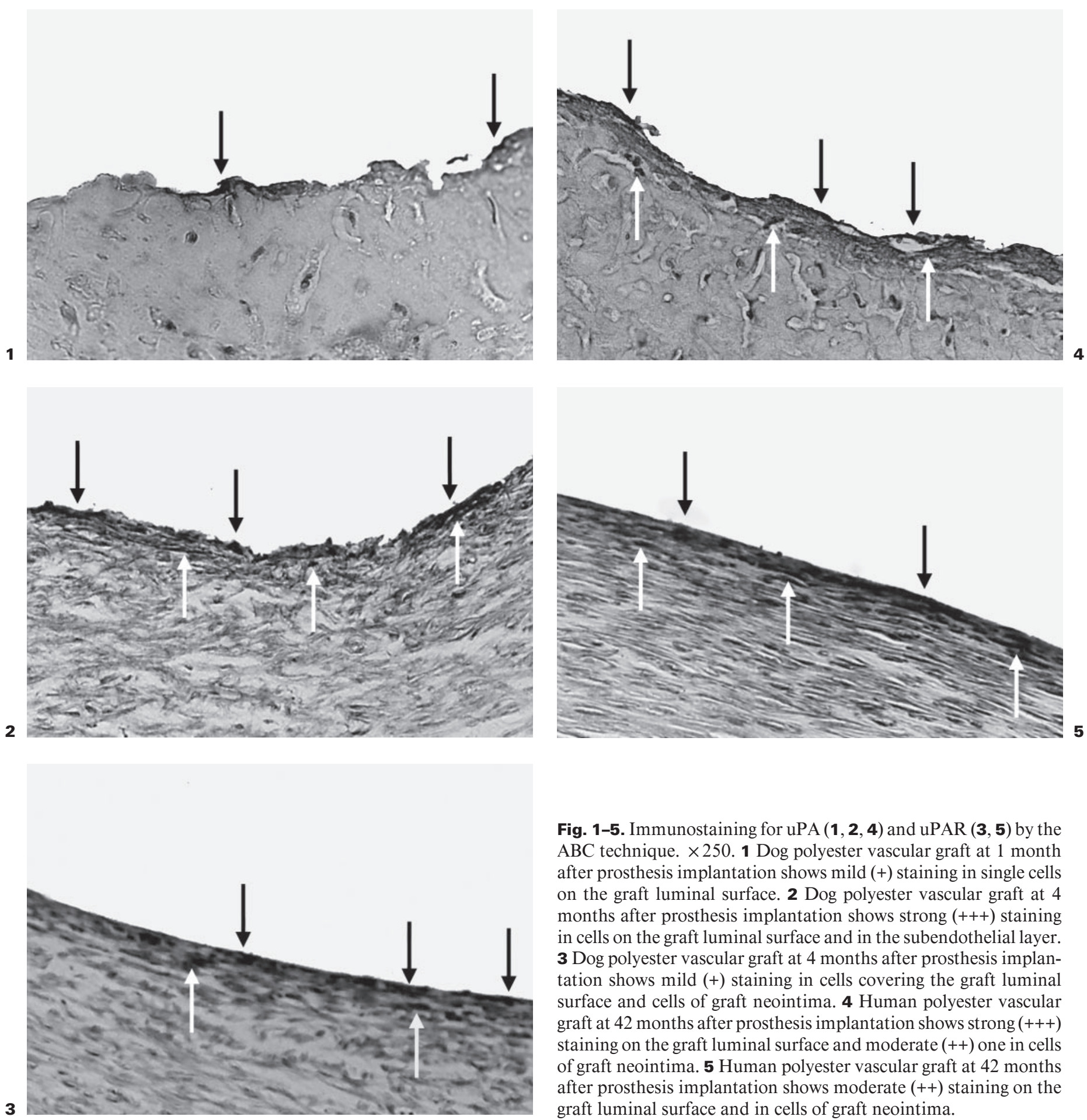

Fig. 1-5. Immunostaining for $\operatorname{uPA}(\mathbf{1}, \mathbf{2}, \mathbf{4})$ and $\operatorname{uPAR}(\mathbf{3}, \mathbf{5})$ by the ABC technique. $\times 250.1$ Dog polyester vascular graft at 1 month after prosthesis implantation shows mild $(+)$ staining in single cells on the graft luminal surface. 2 Dog polyester vascular graft at 4 months after prosthesis implantation shows strong (+++) staining in cells on the graft luminal surface and in the subendothelial layer. 3 Dog polyester vascular graft at 4 months after prosthesis implantation shows mild $(+)$ staining in cells covering the graft luminal surface and cells of graft neointima. 4 Human polyester vascular graft at 42 months after prosthesis implantation shows strong $(+++)$ staining on the graft luminal surface and moderate $(++)$ one in cells of graft neointima. 5 Human polyester vascular graft at 42 months after prosthesis implantation shows moderate $(++)$ staining on the graft luminal surface and in cells of graft neointima. 
Furthermore, we cannot exclude a higher detection limit of the anti-uPA antibodies used in dog tissues compared with human tissues. If that was the case, even trace uPA expression would have been demonstrated in normal dog aorta, if more specific antibodies had been employed.

We found strong uPA staining in the neointima of human polyester vascular grafts. However, in the early period of graft healing only mild expression of uPA was demonstrated in dogs, but its intensity increased with time following prosthesis implantation. This observation could reflect enhanced coverage of the anastomotic region with endothelial cells [22, 23]. Furthermore, smooth muscle cells and macrophages are getting more numerous in graft neointima, which may also explain the changes observed in UPA expression [23-25].

Comparable uPA labeling before and after 3 months from prosthesis implantation in human prosthetic grafts was shown by other authors [8]. When comparing these findings with our results obtained in dogs, species differences in UPA expression can again be supposed. However, mild uPA staining at 1 month can become quickly enhanced, when smooth muscle cells appear to be dominating ones in graft neointima at about 2 months from prosthesis implantation $[2,26]$. It seems reasonable to assume that periods of 1 and 4 months allow better assessment of changes in uPA expression in the early process of graft healing, than only one period of 3 months.

Negative uPAR staining in normal dog and human aorta confirms the results of previous studies [17]. We managed to demonstrate uPAR expression in the neointima of polyester vascular grafts at anastomotic regions. However, in dogs, it was absent at 1 month and appeared at 4 months after prosthesis implantation. uPAR accelerates cell migration and proliferation in graft neointima. It was shown previously, that 4 months after prosthesis implantation in dogs the graft luminal surface was covered with endothelial cells [22]. Furthermore, graft neointima in the region of the anastomosis is much thicker at 4 and 12 months than at 1 month of the study.

Comparable UPAR expression was shown previously in human prosthetic vascular grafts before and after 3 months from prosthesis implantation [8]. We could not evaluate the early period of graft healing in humans; however, in dogs, we found significantly different uPAR expression even at 4 and 12 months after prosthesis implantation. These discrepancies can result from differences in the healing process of synthetic vascular grafts. Prostheses in humans are implanted into arteries with an advanced atherosclerotic process, whereas in experimental animals they are implanted into unchanged ones. Smooth muscle cells in atherosclerotic lesions express uPAR [17], which can lead to their earlier appearance and increased uPAR staining in the neointima of human grafts, when compared to the neointima of vascular grafts in experimental models.

The uPA system increases the fibrinolytic potential of the neointima and prevents graft thrombosis on the one hand, whereas on the other hand it enhances intimal growth by initiating a proteolytic cascade of matrix degradation and cell migration [12, 25, 27]. This diminishes the enthusiasm for uPA as an important factor favoring the maintenance of graft patency, particularly when uPAR expression appears in the neointima in the region of the graft anastomosis in the late period after prosthesis implantation. It can even be hypothesized that simultaneous UPA and UPAR expression, by predisposing to neointima instability, may be implicated in graft wall injury and paradoxically trigger thrombosis by exposing subendothelial tissue [7, 8]. Moreover, neointima instability combined with other factors may also favor the formation of anastomotic pseudoaneurysms in the late postoperative period [28].

It can be concluded that in the early period of the healing process of polyester vascular grafts only urokinase is present in the neointima at the graft to adjacent artery anastomosis. Whereas with time following prosthesis implantation both in dogs and in humans, expression of uPAR is found as well. 


\section{References}

1 Glowinski S, Worowski K: The haemostatic system components of neointima forming in polyester aortic grafts in the early postoperative period. Haematologia 1981;14:393-398.

-2 Sato O, Tada Y, Takagi A: The biologic fate of Dacron double velour vascular prostheses - a clinicopathological study. Jpn J Surg 1989;3: 301-311.

$\checkmark 3$ Lemson SM, Tordoir JHM, Daemen MJAP, Kitslaar PJEHM: Intimal hyperplasia in vascular grafts. Eur J Vasc Surg 2000;19:336351.

$\checkmark 4$ Lin PH, Bush RL, Yao Q, Lumsden AB, Chen $\mathrm{C}$ : Evaluation of platelet deposition and neointimal hyperplasia of heparin-coated smallcaliber ePTFE grafts in a canine femoral artery bypass model. J Surg Res 2004;118:45-52.

$\checkmark 5$ Yao JS, Bergan JJ, Kwaan HC: Quantification of fibrinolytic activity in venous and prosthetic arterial grafts. Arch Surg 1974;109:163167.

6 Earnshaw JJ, Westby JC, Makin GS, Hopkinson BR: Defective fibrinolysis: A risk factor in early femoropopliteal graft thrombosis. $\mathrm{Br} \mathrm{J}$ Surg 1987;74:932-935.

7 Sirén V, Kauhanen P, Carpen O, Luther M, Lepantalo M, Vaheri A, Lassila R: Urokinase, tissue-type plasminogen activator and plasminogen activator inhibitor-1 expression in severely stenosed and occluded vein grafts with thrombosis. Blood Coagul Fibrinolysis 2003; 14:369-377.

$\checkmark 8$ Urayama H, Katada S, Kasashima F, Tanaka Y, Kawasuji K, Watanabe Y: Plasminogen activators, matrix metalloproteinases and their inhibitors in implanted vascular prostheses. Eur J Vasc Endovasc Surg 2000;20:501-507.

-9 Prager MR, Hoblaj T, Nanobashvili J, Sporn E, Polterauer P, Wagner O, Böhmig H-J, Teufelsbauer H, Ploner M, Huk I: Collagenversus gelatine-coated Dacron versus stretch PTFE bifurcation grafts for aortoiliac occlusive disease: Long-term results of a prospective, randomised multicenter trial. Surgery 2003; 134:80-85.
10 Camoin L, Pannell R, Anfosso F, Lefevre JP, Sampol J, Gurewich V, Dignat-George F: Evidence for the expression of urokinase-type plasminogen activator by human venous endothelial cells in vivo. Thromb Haemost 1998;80: 961-967.

11 Chavakis T, Willuweit AK, Lupu F, Preissner KT, Kanse SM: Release of soluble urokinase receptor from vascular cells. Thromb Haemost 2001;86:686-693.

12 Falkenberg M, Tom C, DeYoung MB, Wen S, Linnemann R, Dichek DA: Increased expression of urokinase during atherosclerotic lesion development causes arterial constriction and lumen loss, and accelerates lesion growth. Proc Natl Acad Sci USA 2002;99:10665-10670.

13 Mignatti P, Rifkin DB: Plasminogen activators and matrix metalloproteinases in angiogenesis. Enzyme Protein 1996;49:117-137.

14 Collen D, Stassen JM, Stump DC, Verstraete M: Synergism of thrombolytic agents in vivo. Circulation 1986;74:838-842.

15 Solberg H, Ploug M, Hoyer-Hansen G, Nielsen BS, Lund LR: The murine receptor for urokinase-type plasminogen activator is primarily expressed in tissues actively undergoing remodeling. J Histochem Cytochem 2001;49: 237-246.

16 Rabbani SA, Mazar AP: The role of the plasminogen activation system in angiogenesis and metastasis. Surg Oncol Clin N Am 2001;10: 393-415.

17 Salame MY, Samani NJ, Masood I, deBono DP: Expression of the plasminogen activator system in the human vascular wall. Atherosclerosis 2000;152:19-28.

18 Yates SG, Barros D'Sa AA, Berger K, Fernandez LG, Wood SJ, Rittenhouse EA, Davis CC, Mansfield PB, Sauvage LR: The preclotting of porous arterial prostheses. Ann Surg 1978;188: 611-622.

19 Sato Y, Mukai K, Watanabe S, Goto M, Shimosato Y: The AMeX method. A simplified technique of tissue processing and paraffin embedding with improved preservation of antigens for immunostaining. Am J Pathol 1986; 125:431-435.

20 Hsu SM, Raine L, Fanger H: Use of avidinbiotin-peroxidase complex (ABC) in immunoperoxidase techniques: A comparison between $\mathrm{ABC}$ and unlabeled antibody (PAP) procedures. J Hist Cytochem 1981;29:577-580.
21 Schneiderman J, Bordin GM, Engelberg I, Adar R, Seiffert D, Thinnes T, Bernstein EF, Dilley RB, Loskutoff DJ: Expression of fibrinolytic genes in atherosclerotic abdominal aortic aneurysm wall. A possible mechanism for aneurysm expansion. J Clin Invest 1995;96: 639-645.

22 Kowalewski R, Zimnoch L, Wojtukiewicz MZ, Glowinski S, Glowinski J: Coagulation activators and inhibitors in the neointima of polyester vascular grafts. Blood Coagul Fibrinolysis 2003; 14:433-439.

23 Levin EG, Loskutoff DJ: Cultured bovine endothelial cells produce both urokinase and tissue-type plasminogen activators. J Cell Biol 1982;94:631-636.

24 Shi Q, Wu MHD, Hayashida N, Wechazek AR, Clowes AW, Sauvage LR: Proof of fallout endothelialization of impervious Dacron grafts in the aorta and inferior vena cava of the dog. J Vasc Surg 1994;20:546-557.

$\checkmark 25$ Clowes AW, Clowes MM, Au YPT, Reidy MA, Belin D: Smooth muscle cells express urokinase during mitogenesis and tissue-type plasminogen activator during migration in injured rat carotid artery. Circ Res 1990;67:61-67.

26 Stewart GJ, Essa N, Chang KHY, Reichle FA: A scanninig and transmission electron microscope study of the luminal coating on Dacron prostheses in the canine thoracic aorta. J Lab Clin Med 1975;85:208-226.

$\checkmark 27$ Lijnen RH, Van Hoef B, Lupu F, Moons L, Carmeliet P, Collen D: Function of the plasminogen/plasmin and matrix metalloproteinases system after vascular injury in mice with targeted inactivation of fibrinolytic system genes. Arterioscler Thromb Vasc Biol 1998;18: 1035-1045.

28 Ylönen K, Biancari F, Leo E, Rainio P, Salmela E, Lahtinen J, Satta J, Pokela R, Lepojärvi M, Juvonen T: Predictors of development of anastomotic femoral pseudoaneurysms after aortobifemoral reconstruction for abdominal aortic aneurysm. Am J Surg 2004; 187:83-87. 